JURNAL MAKSIPRENEUR, Vol. VI, No. 2, Juni 2017, hal. 77 - 86

\title{
DAMPAK DILAKUKANNYA PENGURANGAN TENAGA KERJA: PENGARUH JOB INSECURITY TERHADAP KEPUASAN KERJA DENGAN ASPEK DEMOGRAFIS SEBAGAI VARIABEL MODERATOR
}

\author{
Yafet Eko Kurniawan \\ Tutuk Ari Arsanti \\ Fakultas Ekonomika dan Bisnis Universitas Kristen Satya Wacana Salatiga \\ Korespondensi penulis: tutuk.arsanti@staff.uksw.edu
}

\begin{abstract}
The objective of this study was to describe the effect of job insecurity on job satisfaction and demographic aspects as moderator variables. Demographics such as gender and age of past research showed that women have a higher job insecurity than men and also with age, the less employees feel a threat to their jobs. Quantitative methods through a survey used in this study. The results showed that job insecurity influence on job satisfaction, gender and age moderated the effect of job insecurity on job satisfaction.
\end{abstract}

Keywords: job insecurity, job satisfaction, demographic aspects

\section{PENDAHULUAN}

Pengurangan jumlah tenaga kerja merupakan salah satu alternatif bagi perusahaan dalam rangka meningkatkan efisiensi dan produktivitas karena adanya pengurangan biaya tenaga kerja. Berbagai upaya seperti rekayasa ulang pekerjaan sampai dengan pengurangan tugas dan jumlah tenaga kerja bahkan penyesuaian hirarki struktural dan perampingan dilakukan untuk peningkatan efisiensi dan produktivitas (Sahdev \& Vinnicombe, 1998). Perampingan dan pengurangan tenaga kerja tersebut pada satu sisi dapat membantu perusahaan mencapai efisiensinya, tetapi pada sisi lain menimbulkan dampak negatif terhadap psikologis karyawan seperti adanya perasaan tidak aman atau yang disebut job insecurity. Bagi karyawan yang diberhentikan, kebutuhan untuk diri sendiri dan keluarga menjadi tidak maksimal atau bahkan tidak dapat mencukupi karena dapat mengalami kesulitan dalam mencari dan mendapatkan pekerjaan di tempat lain, sedangkan bagi karyawan yang tidak mengalami pemutusan hubungan kerjapun dapat berpotensi mengalamai perasaan tidak aman, cemas atau bahkan stress yang berlebih atas keberlangsungan pekerjaan mereka. Munculnya dampak psikologis yang dirasakan oleh individu yaitu job insecurity atas kebijakan perusahaan dalam mengurangi jumlah pekerja dapat menurunkan kepuasan kerja, bahkan mengakibatkan banyak konsekuensi negatif terhadap perilaku individu (Band \& Tustin, 1999). Demikian halnya, Robbins (1966: 179) juga menjelaskan bahwa munculnya rasa takut akan penurunan jabatan dan kehilangan pekerjaan yang mengancam kondisi kerja, sehingga dapat menurunkan kepuasan kerja.

Penelitian terdahulu menjelaskan bahwa adanya perbedaan aspek demografis seperti jenis kelamin dan usia dapat memperkuat atau memperlemah pengaruh job insecurity terhadap kepuasan kerja yang dihasilkan. Penelitian terdahulu yang menjelaskan bahwa perempuan memiliki tingkat job insecurity yang lebih tinggi dibandingkan laki-laki 
di tempat kerja (Kinnunen et al, 2000; Näswall \& De Witte, 2003). Hal tersebut dimungkinkan karena adanya kesulitan bagi perempuan untuk mendapatkan pekerjaan baru dibandingkan dengan laki-laki. Faktor usia juga dapat menjadi salah satu faktor dalam melakukan pengurangan karyawan di tempat kerja. Dengan demikian, faktor usia dapat mempengaruhi job insecurity yang berbeda atas kemungkinan kehilangan pekerjaan di kemudian hari. Dalam penelitian ini, peneliti hendak mengkaji apakah ada perbedaan antara jenis kelamin dan usia yang berpotensi menjadi variabel moderator dalam pengaruh job insecurity terhadap kepuasan kerja. Masalah yang hendak diteliti tersebut dijabarkan menjadi sejumlah persoalan berikut ini:

1. Apakah job insecurity berpengaruh negatif terhadap kepuasan kerja?

2. Apakah variabel jenis kelamin memoderasi pengaruh job insecurity terhadap kepuasan kerja?

3. Apakah variabel umur memoderasi pengaruh job insecurity terhadap kepuasan kerja?

\section{KERANGKA TEORITIS}

\section{a. Pengaruh Job Insecurity terhadap Kepuasan Kerja}

Job insecurity mengacu pada persepsi tentang kondisi kerja, khususnya mengenai kehilangan stabilitas pekerjaan dan kontinuitas hubungan kerja dengan organisasi. Job insecurity adalah penilaian subjektif individu tentang potensi kehilangan pekerjaan di masa yang akan datang, dan hal tersebut dapat mengurangi kepercayaan terhadap stabilitas pekerjaan di masa depan. Job insecurity dapat menimbulkan dampak psikologis seperti munculnya rasa marah, murung, bersalah dan khawatir dalam diri karyawan karyawan. Kondisi tersebut lebih lanjut dapat menurunkan kepuasan kerja dan sejumlah konsekuensi lainnya seperti menurunnya kreatifitas dan kinerja karyawan. Beberapa studi telah menemukan bahwa job insecurity yang dirasakan karyawan berpengaruh negatif dan signifikan terhadap kepuasan kerja (Yasadiputra \& Putra, 2014; Martini \& Waluyo, 2014; Pramono, 2004; Farida, 2001; Setiawan \& Putra, 2016; Devi \& Sudibia, 2015). Berdasarkan sejumlah hasil penelitian yang ada, maka dapat dirumuskan hipotesis pertama sebagai berikut:

H1: Job insecurity berpengaruh negatif terhadap kepuasan kerja.

\section{b. Aspek Demografis Memoderasi Pengaruh Job Insecurity terhadap Kepuasan Kerja}

Beberapa studi telah menemukan bahwa karakteristik individu seperti jenis kelamin dapat memoderasi dalam kaitannya antara job insecurity dengan kepuasan kerja (Kinnunen et al, 2000; Okurame, 2014). Job insecurity yang dirasakan oleh laki-laki menimbulkan dampak yang lebih besar daripada wanita. Sementara itu, hasil penelitian karyawan di bank menunjukkan sebaliknya, yaitu job insecurity yang dirasakan wanita yang bekerja pada bank dan pabrik lebih tinggi jika dibandingkan dengan pria (Kinnunen, dkk, 2000).

Karakteristik individu lain yaitu usia dapat pula menjadi moderator dalam memprediksi pengaruh job insecurity terhadap kepuasan kerja. Hasil penelitian terdahulu menunjukkan bahwa usia memperlemah pengaruh job insecurity terhadap kepuasan kerja (Galih Pramono, 2004). Seiring bertambahnya usia karyawan, job insecurity dirasakan semakin berkurang. Sebagai contoh, karyawan di usia 30an dan 40an cenderung lebih bertanggung jawab dalam membesarkan anak-anak, sehingga kemungkinan kehilangan pekerjaan lebih kecil daripada karyawan yang hanya bertanggung jawab atas diri mereka sendiri (DeWitte, 1999). Berdasarkan uraian di atas, dapat dirumuskan hipotesis sebagai berikut: 
H2: Jenis kelamin memoderasi pengaruh job insecurity terhadap kepuasan kerja.

H3: Usia memoderasi pengaruh job insecurity terhadap kepuasan kerja.

\section{Kerangka Pemikiran}

Berdasarkan uraian dalam telaah teoritis yang ada, dapat digambarkan sebagai berikut ini.

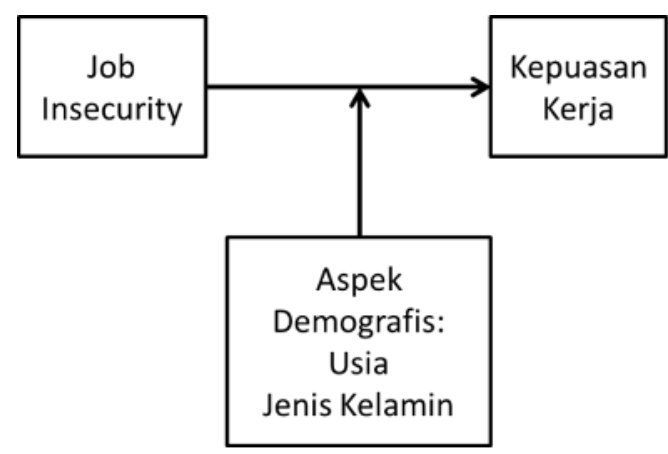

Gambar 1: Kerangka Pemikiran Penelitian

\section{METODE PENELITIAN}

Metode penelitian ini adalah kuantitatif melalui survei. Menurut Sugiyono (2008), metode kuantitatif adalah pendekatan ilmiah yang memandang suatu realitas itu dapat diklasifikasikan, konkrit, teramati, dan terukur. Hubungan antarvariabel bersifat sebab akibat, yaitu data penelitiannya berupa angka-angka dan analisisnya menggunakan statistic, sedangkan menurut Zikmund (1997), metode penelitian survei adalah satu bentuk teknik penelitian ketika informasi dikumpulkan dari sejumlah sampel yang terdiri atas responden untuk kemudian diminta mengisi angket.

\section{Populasi dan Sampel}

Populasi pada penelitian ini adalah karyawan bagian produksi di salah satu perusahaan tekstil sejumlah 200 orang. Teknik pengambilan sampel menggunakan teknik accidental sampling, yaitu teknik penentuan sampel berdasarkan kebetulan. Dengan demikian, karyawan produksi yang secara kebetulan bertemu dengan peneliti dan dinilai memiliki informasi yang dibutuhkan dijadikan sebagai sumber data yang dapat digunakan sebagai sampel dalam penelitian ini (Sugiyono, 2001: 60). Penentuan jumlah sampel dihitung dengan menggunakan rumus Slovin (Sevilla et. al., 1993: 161) yaitu:

$$
\mathrm{n}=\mathrm{N} / 1+\mathrm{Ne}^{2}
$$

Dengan demikian, jumlah sampel minimum yang diambil adalah 67 responden.

\section{Jenis dan Sumber Data}

Data primer dalam penelitian ini didapatkan dari kuesioner yang dibagikan kepada karyawan sebagai responden dalam penelitian ini untuk kemudian diminta mengisi kuesioner secara langsung. Sementara data sekunder diperoleh dari jurnal, dan informasi yang diperoleh melalui internet yang berhubungan dengan persoalan yang diteliti.

\section{Alat Ukur}

Penelitian ini menggunakan alat ukur yang diadopsi dan dimodifikasi dari penelitian sebelumnya. Alat ukur untuk variabel job insecurity menggunakan sumber dari Greenhalgh dan Rosenblatt (1984). Pengukuran variabel kepuasan kerja menggunakan 
sumber dari Brayfield dan Rothe (1951). Skala pengukuran menggunakan skala 1 sampai dengan 5 yaitu dari sangat tidak setuju (STS) sampai dengan sangat setuju (SS) seperti yang ditunjukkan di bawah ini.

Sangat tidak setuju (STS)

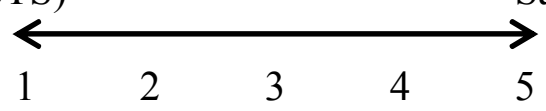

Sangat Setuju (SS)

Pengujian validitas digunakan untuk mengukur valid atau tidaknya kuesioner. Uji validitas dapat dihitung sebagai berikut:

$$
r=\frac{n\left(\sum X\right)-\left(\sum Y\right)}{\sqrt{n}\left(\left(\sum X^{2}\right)-\left(\sum X\right)^{2}\right)\left(\left(\sum Y\right)^{2}-\left(\sum Y\right)^{2}\right)}
$$

Berdasarkan hasil uji validitas dan uji reliabilitas terhadap instrumen yang digunakan, maka diperoleh hasil sebagai berikut:

Tabel 1. Hasil Uji Validitas

\begin{tabular}{|l|r|r|l|}
\hline Variabel/Indikator & Kisaran r hitung & r tabel & Keterangan \\
\hline Job insecurity (x) & 0,237 & 0,2146 & Valid \\
\hline Item 1 & 0,466 & 0,2146 & Valid \\
\hline Item 2 & 0,414 & 0,2146 & Valid \\
\hline Item 3 & 0,830 & 0,2146 & Valid \\
\hline Item 4 & 0,855 & 0,2146 & Valid \\
\hline Item 5 & 0,246 & 0,2146 & Valid \\
\hline Item 6 & 0,789 & 0,2146 & Valid \\
\hline Item 7 & \multicolumn{5}{|l|}{} \\
\hline Kepuasan Kerja (y) & 0,577 & 0,2146 & Valid \\
\hline Item 1 & 0,764 & 0,2146 & Valid \\
\hline Item 2 & 0,790 & 0,2146 & Valid \\
\hline Item 3 & 0,841 & 0,2146 & Valid \\
\hline Item 4 & 0,806 & 0,2146 & Valid \\
\hline Item 5 & 0,842 & 0,2146 & Valid \\
\hline Item 6 & 0,882 & 0,2146 & Valid \\
\hline Item 7 & \multicolumn{5}{|l|}{} \\
\hline
\end{tabular}

r-hitung keseluruhan indikator positif dan lebih besar dari nilai r-tabel yang besarnya adalah 0,2146 menggunakan tingkat signifikan 0,05. Nilai r-tabel diambil dengan menggunakan rumus $\mathrm{df}=\mathrm{n}-2$ (Ghozali dalam Mahesa, 2010), sehingga menghasilkan nilai r-tabel sebesar 0,2146. Dari hasil uji validitas di atas dapat disimpulkan bahwa semua indikator dalam penelitian ini dinyatakan valid, sedangkan pengujian reliabilitas digunakan untuk mengukur keandalan jawaban terhadap kuesioner tersebut konsisten dari waktu ke waktu. Alat ukurnya dapat diukur menggunakan program SPSS dengan uji statistik cronbach alpha $(\alpha)$. Uji cronbach alpha dapat dihitung sebagai berikut:

$$
\alpha=\frac{k \cdot r}{1+(k-1) r}
$$


Jika nilai $\alpha>0,60$ maka variabel tersebut dinyatakan reliabel (Ghozali dalam Mahesa, 2010). Dari hasil uji reliabilitas di atas dapat disimpulkan bahwa butir indikator dalam penelitian ini dikatan reliabel.

Tabel 3.2. Hasil Uji Reliabilitas

\begin{tabular}{|l|r|r|l|}
\hline Variabel/Indikator & Cronbach's Alpha & $\boldsymbol{\alpha}$ & Keterangan \\
\hline Job insecurity(x) & 0,641 & 0,60 & Reliabel \\
\hline Item 1 & 0,695 & 0,60 & Reliabel \\
\hline Item 2 & 0,642 & 0,60 & Reliabel \\
\hline Item 3 & 0,660 & 0,60 & Reliabel \\
\hline Item 4 & 0,474 & 0,60 & Reliabel \\
\hline Item 5 & 0,459 & 0,60 & Reliabel \\
\hline Item 6 & 0,686 & 0,60 & Reliabel \\
\hline Item 7 & 0,500 & 0,60 & Reliabel \\
\hline Kepuasan Kerja(y) & 0,897 & 0,60 & Reliabel \\
\hline Item 1 & 0,912 & 0,60 & Reliabel \\
\hline Item 2 & 0,884 & 0,60 & Reliabel \\
\hline Item 3 & 0,881 & 0,60 & Reliabel \\
\hline Item 4 & 0,873 & 0,60 & Reliabel \\
\hline Item 5 & 0,879 & 0,60 & Reliabel \\
\hline Item 6 & 0,873 & 0,60 & Reliabel \\
\hline Item 7 & 0,866 & 0,60 & Reliabel \\
\hline
\end{tabular}

\section{Alat Analisis}

Hasil pengukuran dengan metode kuantitatif diharapkan dapat memberikan hasil pengukuran yang lebih akurat mengenai tanggapan responden. Data yang telah dikumpulkan dari kuesioner akan dihitung menggunakan SPSS. Metode analisis data dengan perhitungan statistik menggunakan SPSS dipakai untuk menguji hipotesis dapat diterima atau ditolak. Penelitian ini menggunakan model analisis regresi yang dapat dihitung dengan rumus:

$$
\mathrm{Y}=\mathrm{a}+\mathrm{bx}
$$

Uji nilai selisih mutlak adalah aplikasi khusus regresi linier berganda untuk menguji pengaruh moderasi dengan nilai selisih mutlak dari variabel independen.

$$
\mathrm{Y}=\left(\mathrm{b}_{1} \mathrm{X}_{1}+\mathrm{b}_{2} \mathrm{X}_{2}+\mathrm{b}_{3} \mathrm{abs} \mathrm{X}_{1 \_} \mathrm{X}_{2}\right)+\left(\mathrm{b}_{1} \mathrm{X}_{1}+\mathrm{b}_{4} \mathrm{X}_{3}+\mathrm{b}_{5} \mathrm{abs} \mathrm{X}_{1 \_} \mathrm{X}_{3}\right)
$$

\section{HASIL PENELITIAN DAN PEMBAHASAN}

Hasil penelitian dari data yang telah diperoleh dengan kuesioner yang telah disebarkan pada karyawan bagian spinning di PT Daya Manunggal Damatex Salatiga, sebagai obyek dan lokasi penelitian yang dianalisis dalam penelitian ini. Hasil data yang telah dianalisis dapat digunakan untuk mengetahui adanya pengaruh yang terjadi antara job insecurity terhadap kepuasan kerja karyawan dan digunakan juga untuk menarik kesimpulan atas hipotesis yang diuji.

\section{Profil Penelitian}

Populasi dalam penelitian ini adalah karyawan bagian produksi di sebuah perusahaan manufaktur yang berjumlah 200 karyawan. Sebanyak 84 karyawan diambil sebagai sampel dalam penelitian ini. Dari sampel yang diambil, 33,33\% adalah laki-laki 
dan $66,67 \%$ adalah perempuan, sedangkan dari usia, sebanyak 2,43\% berusia kurang atau sama dengan 20 tahun, 10,7\% berusia antara 21-30 tahun, sebanyak $25 \%$ berusia antara 31-40 tahun, 58,3\% berusia antara 41-50 tahun, dan sebanyak 3,57\% berusia lebih atau sama dengan 51 tahun. Berdasarkan gambara usia yang ada, sebagian besar karyawan berusia antara 41 sampai 50 tahun sebanyak 49 orang atau $58.3 \%$. Pada usia produktif tersebut, karyawan yang dinilai sudah memiliki banyak pengalaman dan dapat diandalkan. Responden dalam penelitian ini adalah karyawan yang masih bekerja dan tidak atau belum mengalami perampingan. Namun, proses perampingan yang dilakukan perusahaan sebelumnya dapat memiliki dampak secara psikologis bagi karyawan yang tidak atau belum mengalami perampingan.

\section{Uji Asumsi Klasik}

Uji Normalitas bertujuan untuk mengetahui apakah dalam model regresi, variabel pengganggu atau residual memiliki distribusi normal atau tidak. Dari hasil uji normalitas dengan menggunakan non-parametrik kolmogorov-smirnov diketahui bahwa p-value adalah 0,200 dan lebih besar dari 0,05, maka dapat disimpulkan data yang digunakan terdistribusi normal

Tabel 2. Hasil Uji Normalitas

One-Sample Kolmogorov-Smirnov Test

\begin{tabular}{|c|c|c|}
\hline & & $\begin{array}{l}\text { Unstandardiz } \\
\text { ed Residual }\end{array}$ \\
\hline$N$ & & 84 \\
\hline \multirow{2}{*}{ Normal Parameters ${ }^{a, b}$} & Mean & .0000000 \\
\hline & Std. Deviation & 4.15653774 \\
\hline \multirow[t]{3}{*}{ Most Extreme Differences } & Absolute & .067 \\
\hline & Positive & .067 \\
\hline & Negative & -.066 \\
\hline \multicolumn{2}{|l|}{ Test Statistic } & .067 \\
\hline \multicolumn{2}{|l|}{ Asymp. Sig. (2-tailed) } & $200^{c, d}$ \\
\hline \multicolumn{3}{|c|}{ a. Test distribution is Normal. } \\
\hline \multicolumn{3}{|l|}{ b. Calculated from data. } \\
\hline \multicolumn{3}{|c|}{ c. Lilliefors Significance Correction. } \\
\hline \multicolumn{3}{|c|}{ d. This is a lower bound of the true significance. } \\
\hline
\end{tabular}

\section{HASIL PENELITIAN}

\section{Pengaruh Job insecurity terhadap Kepuasan Kerja}

Hasil dari regresi variabel job insecurity terhadap kepuasan kerja menunjukkan bahwa pengaruh job insecurity terhadap kepuasan kerja karyawan adalah $0,056\left(\mathrm{R}^{2}\right)$, yang berarti bahwa kepuasan kerja dipengaruhi oleh job insecurity sebesar 5,6\% sedangkan sisanya $94,4 \%$ kepuasan kerja dipengaruhi oleh faktor lain. Dengan nilai signifikansi $0,03<5 \%$ maka job insecurity dapat digunakan untuk memprediksi kepuasan kerja. Dengan demikian hipotesis 1 yang diajukan dapat diterima. Berdasarkan uji regresi yang dilakukan. maka diperoleh hasil sebagai berikut: 
Tabel 3. Hasil Regresi Bertingkat Pengaruh Job insecurity tehadap Kepuasan Kerja

\begin{tabular}{|c|l|c|c|c|c|}
\hline Mode & \multicolumn{1}{|c|}{ Variabel } & $\mathbf{R}^{2}$ & F & Sig. F & B \\
\hline 1 & $\begin{array}{l}\text { Job insecurity terhadap kepuasan } \\
\text { kerja }\end{array}$ & $5,6 \%$ & 4.905 & 0.030 & 31.206 \\
\hline 2 & $\begin{array}{l}\text { Job insecurity terhadap kepuasan } \\
\text { kerja dengan variabel jenis } \\
\text { kelamin }\end{array}$ & $13 \%$ & 3.974 & 0.011 & 32.586 \\
\hline 3 & $\begin{array}{l}\text { Job insecurity terhadap kepuasan } \\
\text { kerja dengan variabel umur }\end{array}$ & $24,2 \%$ & 8.517 & 0.000 & 9.006 \\
\hline
\end{tabular}

Sumber: data primer yang diolah.

\section{Jenis Kelamin Sebagai Variabel Moderator pada Pengaruh Job Insecurity terhadap Kepuasan Kerja}

Hasil dari regresi variabel job insecurity terhadap kepuasan kerja dengan variabel jenis kelamin sebesar $13 \%$ sedangkan sisanya $87 \%$ di pengaruhi oleh faktor lain. Dengan nilai signifikansi $0,011<0,05$ dapat diartikan bahwa job insecurity dan jenis kelamin dapat digunakan untuk memprediksi kepuasan kerja dan hipotesis 2 diterima. Dengan demikian, pengaruh job insecurity terhadap kepuasan kerja yang dimoderasi oleh jenis kelamin signifikan.

\section{Umur Sebagai Variabel Moderator pada Pengaruh Job Insecurity terhadap Kepuasan Kerja}

Hasil dari regresi variabel job insecurity terhadap kepuasan kerja di moderasi oleh variabel umur adalah sebesar $24,2 \%$ sedangkan sisanya $75,8 \%$ di pengaruhi oleh faktor lain. Dengan nilai signifikansi sebesar $0,000<0,05$ dapat diartikan bahwa job insecurity dan umur dapat digunakan untuk memprediksi kepuasan kerja. Dengan demikian hipotesis 3 diterima karena job insecurity yang dimoderasi oleh variabel umur berpengaruh secara signifikan terhadap kepuasan kerja.

\section{PEMBAHASAN}

Hasil penelitian menunjukkan bahwa masih terdapat kemungkinan sejumlah variabel lain selain job insecurity yang dapat berpengaruh terhadap kepuasan kerja karyawan. Hal tersebut ditunjukkan dengan nilai $\mathrm{F}$ hanya sebesar 5,6\%. Masih adanya kemungkinan bahwa variabel lain seperti kompensasi, lingkungan kerja, promosi jabatan, kondisi kerja, serta faktor lain dapat mempengaruhi kepuasan kerja karyawan. Meskipun demikian, job insecurity mempunyai pengaruh yang signifikan terhadap kepuasan kerja. Munculnya perasaan job insecurity seperti adanya kemungkinan dirumahkan, pemindahan lokasi pekerjaan, diberhentikan, atau penurunan level pekerjaan terhadap karyawan bahkan ketidakpastian terhadap keberlangsungan kerja dapat berpengaruh terhadap kepuasan kerja yang dirasakan oleh karyawan. Dengan demikian, persoalan perampingan mestinya mendapat perhatian lebih oleh perusahaan. Adanya potensi pengurangan tenaga kerja dapat mengganggu bahkan merusak konteks sosial yang dimiliki oleh karyawan, sehingga dimungkinkan munculnya konsekuensi negatif lainnya bahkan penurunan kinerja karyawan. Hasil penelitian ini mendukung hasil-hasil penelitian terdahulu (Pramono, 2004; Devi \& Sudibia, 2016; Farida, 2001; Martini \& Waluyo, 2014; Setiawan \& Putra, 2014) yang menyimpulkan bahwa job insecurity berpengaruh secara negatif dan signifikan terhadap kepuasan kerja.

Hasil penelitian ini membuktikan bahwa faktor demografis karyawan seperti jenis kelamin dapat memoderasi pengaruh job insecurity terhadap kepuasan kerja. Jenis kelamin 
yang berbeda mempunyai job insecurity secara berbeda pula, ketika terjadi pengurangan jumlah tenaga kerja di tempat kerjanya. Pada penelitian terdahulu menunjukkan bahwa laki-laki lebih terkena dampak atas job insecurity yang dirasakan sebagai akibat dari pengurangan tenaga kerja di tempat kerja. Hal tersebut dimungkinkan karena laki-laki mempunyai beban dan tanggung jawab ekonomi lebih besar di dalam keluarga pada umumnya. Namun sebaliknya, bagi karyawan perempuan di bank dan pabrik, karyawan perempuan lebih memiliki job insecurity yang lebih tinggi jika dibandingkan dengan pria. Hal tersebut dimungkinkan karena pria dinilai lebih unggul dalam menduduki posisiposisi penting di bank, sehingga dapat melindungi posisi yang mereka miliki, sedangkan karyawan perempuan di pabrik dan departemen sosial dan kesehatan, posisi karyawan pria dengan wanita juga berbeda satu sama lain. Wanita lebih berisiko dalam proses perampingan, karena dominasi pekerja wanita pada bagian produksi yaitu banyak pabrik yang melakukan perampingan pada bagian tersebut, sehingga dengan adanya fenomenafenomena yang terjadi maka wanita lebih merasakan job insecurity dibandingkan laki-laki. Hasil penelitian ini juga memberikan dukungan atas penelitian-penelitian terdahulu.

Berdasarkan hasil penelitian ini dapat diketahui bahwa umur juga dapat menjadi variabel moderator untuk memprediksi pengaruh job insecurity terhadap kepuasan kerja. Hal ini dimungkinkan karena semakin tua usia karyawan, maka semakin tinggi kepuasan kerja yang dirasakan. Hal tersebut dapat terjadi karena seiring bertambahnya usia karyawan, semakin berkurangnya job insecurity yang dirasakan oleh karyawan (Pramono, 2004). Dengan demikian, variabel usia dapat menjadi variabel moderator dalam pengaruh job insecurity terhadap kepuasan kerja. DeWitte (dalam Naswal, et.al. 2003) menjelaskan bahwa, orang-orang di usia 30an dan 40an, berada pada usia yang biasanya telah mempunyai tanggung jawab untuk membesarkan anak-anak, sehingga cenderung mengalami kemungkinan kehilangan pekerjaan lebih negatif daripada orang yang hanya bertanggung jawab atas diri mereka sendiri.

\section{KESIMPULAN}

Berdasarkan hasil penelitian di atas, maka dapat disimpulkan bahwa:

1. Job insecurity berpengaruh secara negatif terhadap kepuasan kerja secara signifikan. Semakin rendah job insecurity yang dirasakan oleh karyawan, maka kepuasan kerja yang dirasakan oleh karyawan semakin tinggi, hal ini menunjukan bahwa hipotesis 1 diterima.

2. Jenis kelamin dapat memoderasi pengaruh job insecurity terhadap kepuasan kerja, hal ini menunjukkan bahwa hipotesis 2 diterima.

3. Usia dapat memoderasi pengaruh job insecurity terhadap kepuasan kerja, hal ini juga menunjukkan bahwa hipotesis 3 diterima.

Dengan demikian, hasil penelitian ini memberikan dukungan atas penelitian terdahulu yaitu job insecurity mempunyai pengaruh yang signifikan terhadap kepuasan kerja. Adanya perbedaan aspek demografis seperti usia dan jenis kelamin menghasilkan perbedaan pengaruh job insecurity terhadap kepuasan kerja yang dialami.

\section{DAFTAR REFERENSI}

Band, D.C. \& Tustin, C.M. (1995). Strategic Downsizing. Management Decision, 33(8): p. 36- 41. 
Bragger, J.D., Kutcher, E.J., Menier, A., Sessa, V.I., \& Sumner, K. (2013). Giving Nonselective Downsizing a Performance Review. Human Resource Development Review. SAGE Publications.

Devi, N.L.M.S. \& Sudibia, A.G. (2015). Analisis Pengaruh Job Insecurity dan Kompensasi Finansial terhadap Kepuasan Kerja dan Turnover Intention (Studi pada Karyawan Kontrak di Bali Dynasty Resort). E-Jurnal Manajemen Unud, Vol 4, No. 4, 2015:1047-1066.

Farida, Y.N. (2001). Pengaruh Job Insecurity dan Kompensasi terhadap Kepuasan Kerja. Universitas Diponegoro. Semarang.

Kinnunen, U., Mauno, S., Natti, J., \& Happonen, M. (2000). Organizational Antecendents and Outcomes of Job Insecurity: A Longitudinal Study in Organizations.

Martini, E., \& Waluyo, L.E.M.. Pengaruh Jangka Pendek Job Insecurity dan Kompensasi terhadap Kepuasan Kerja.

Näswall, K. \& DeWitte, H. (2003). Who Feels Insecure in Europe? Predicting Job Insecurity from Background Variables. Economic and Industrial Democracy, 24(2), p. 189-215, http://dx.doi.org/10.1177/0143831X03024002003.

Okurame, D.E. (2014). Moderator Effects of Gender in the Job Insecurity-Career Engagement Relationship: A Nigerian Study. International Journal of Business and Management, Vol 9. No. 6.

Pramono, G. (2004). Analisis Pengaruh Ketidakamanan Kerja terhadap Kepuasan Kerja dengan Variabel Moderator Umur dan Lama Kerja (Studi Kasus pada Karyawan Bagian Pemasaran PT Batik Danarhadi Surakarta). Skripsi dipublikasikan. www.digilib.uns.ac.id, diakses tanggal 9 November 2009.

Purani, K. \& Sunil, S. (2008). The Moderating Role of Industrial Experience in the Job Satisfaction, Intention to Leave Relationship: An Empirical Study among Salesmen in India. Journal of Business \& Industrial Marketing, Jilid 23, Terbitan 7, p 475-485.

Putra, W. http://analisis-statistika.blogspot.co.id/2012/09/menentukan-jumlah-sampeldengan-rumus.html. 10 Mei 2016.

Robbins, S.P. (1996). Perilaku Organisasi, Konsep, Kontroversi, dan Aplikasi. Alih Bahasa: Hadyana Pujaatmaka. Edisi Keenam. Jakarta: Penerbit PT Bhuana Ilmu Populer.

Sahdev, K. \& Vinnicombe, S. (1998). Downsizing and Survivor Syndrome: A Study of Hr's Perception of Survivors Responses..

Setiawan, R. \& Hadianto, B. Job Insecurity dalam Organisasi. Staf Pengajar Fakultas Ekonomi Jurusan Manajemen Universitas Kristen Maranatha Bandung.

Sugiyono (2008). Metode Penelitian Kunatitatif Kualitatif dan R\&D. Bandung: Alfabeta

Universitas Gunadarma. Karyawan Outsourcing di PT Askes (Persero) Kantor Pusat. (2009).

Utami, I., Bonussyeani, N.E.S. (2009). Pengaruh Job Insecurity, Kepuasan Kerja, dan Komitmen Organisasional terhadap Keinginan Berpindah Kerja. Jurnal Akuntansi dan Kuangan Indonesia. Vol 6, No. 1. 
Yasadiputra, K.A. \& Putra, M.S. (2014). Pengaruh Organizational Justice serta Job insecurity terhadap Job Satisfaction Pegawai Kontrak pada PT Wico Interna, Singaraja, Bali. Jurnal Manajemen Strategi Bisnis dan Kewirausahaan. Vol 8. No. 1.

Zikmund, W.G. et al. (2010). Business Research Methods. Eight Edition. USA: SouthWestern.

http://www.spssindonesia.com/ olah data statistik dengan SPSS, 10 Juni 2016. 